\title{
Land management process of changing the purpose of land plots: state and problems
}

Tretiak A.M. Doctor of Economics, professor

Corresponding Member of the National Academy of Sciences of Ukraine

State Ecology Academy of Postgraduate Education and Management

Dorosh I.M. Doctor of Economics, associate professor

National University of Life and Environmental Sciences of Ukraine

Yu. Lobunko PhD in Economics,

Kamenetz-Podolsky Agrarian-Technical University

E-mail: nnieco@ukr.net

The concept of "intended purpose", "purpose", peculiarities of the change of the purpose of different types of ownership of land plots, stages of land management process of changing land plots purpose was explored. The existing legislative and regulatory problems and ways of their solution are found out.

Keywords: Land management process, change of intended purpose of land use, land management project.

In the conditions of the dynamic development of the land market in Ukraine, landowners and land users have to deal with various legal instruments for solving many problems associated with the use and disposal of land plots. Basically, these problems arise in connection with the restrictions established by the Land Code of Ukraine, other acts of land legislation regarding the land use purpose.

Article 19 of the Land Code of Ukraine [3] states that the lands of Ukraine for the main purpose are divided into nine categories, each of which has its own limitations. For example, land suitable for the needs of agriculture should be provided, primarily for agricultural use (Article 23 of the Land Code of Ukraine), and recreational land is prohibited from activities that impede or prevent the use of their intended purpose, and also adversely affects or may affect the natural conditions of these lands (Part 2 of Article 52 of the Land Code of Ukraine). 
But in the conditions of the "dictate" of a market economy, citizens and legal entities are increasingly faced with the need to use their land plot for a different purpose than that provided by a state act on ownership of a land plot or its state registration. It is sometimes preferable to use a degraded land plot for forestry or construction than for agricultural production, or land provided for farming for recreational purposes. There are many such examples and therefore the question arises about changing the purpose of land.

The purpose of the article is to study the conditions and problems of land management process when changing the purpose of land plots.

Research results. According to paragraph 2 of Article 20 of the Land Code of Ukraine [3] purpose change of land of state or municipal property carried out by the Supreme Council of the Autonomous Republic of Crimea, the Council of Ministers of the Autonomous Republic of Crimea, the executive authority or local authorities who decide on the approval of land management projects on land allocation and transfer of these sites in the ownership or use in accordance with the powers defined in Article 122 of the Code.

The change of the intended purpose of land plots of private property is carried out on the initiative of the owners of land plots and is carried out:

1) in relation to the land plots located within the settlement - village, settlement, city council;

2) in relation to the land plots located outside the settlements, the district (rayon) state administration, and regarding the land plots located outside the settlements that are not part of the district or in case if the district state administration is not formed, - the Council of Ministers of the Autonomous Republic of Crimea, regional (oblast) state administration.

Given the existing provisions of the Land Code of Ukraine, we will systematically analyze the process of changing the purpose of land plots with an emphasis on the main problems that landowners and land users are facing.

In accordance with the principle of the purposeful use of agricultural land enshrined in the Code, they must be used exclusively for their intended purpose. 
Establishing one or another type of intended purpose of a land plot is very important in terms of its further use, since the purpose of the land, for example, for the conduct of commodity agricultural production, requires that its owner must create a business entity that will use this land for the purpose of business activity or plans to transfer it for rent in order to receive rent payments.

However, as practice shows, in the process of land use citizens and legal entities often face the need to use their land for a different purpose than that provided by a state act on ownership of a land plot or its state registration. The most typical cases are when a person who owns the land plot granted to her for the purpose of conducting commodity agricultural production, eventually there is a need to use this land for the management of a private farm, or vice versa. And this is where the question arises about changing the purpose of land. Usually with this serious problem becomes a misunderstanding of the concept of purpose. Citizens are misleading about the inaccuracy of land legislation, which is why they assume mistakes that they sometimes have to pay dearly.

Since the plots granted for private farming and land plots granted for commodity agricultural production are agricultural lands, citizens consider that there is no need to apply to the authorities to change the purpose of land plots.

This is a serious mistake. The fact is that Article 19 of the Land Code of Ukraine [3] refers to the "main purpose", and in Article 20, the term "purpose" is used. Therefore, the requirements for the necessary change of the purpose relate to the transfer of land from not only one category to another, but also a transfer within one category. One can disagree with such an interpretation of the norms of the Land Code of Ukraine, considering the absurd implementation of a complex procedure for changing the purpose, for example, in cases where the person initially transferred the land to the lease, and then decided to work on it independently, creating a farm. At the same time, the land used for growing crops, and will be used for it in the future. With this, you can agree on the economic point of view, but in this particular case, the rules of land legislation are incorrectly understood. 
In our opinion, under the main purpose of land should be understood a set of land legislation requirements of land use. For example, P.F. Kulinich [5] defines the notion of the main purpose of land as the purpose of the land plot, which is defined by the established legislation and specified by the relevant authorities, by the permissible limits of the use of land by citizens and legal entities. Because of changes in the purpose of land, the transfer of land from one category to another is carried out.

According to clause 5 of Article 20 of the Land Code of Ukraine [3], the use of a land plot within a certain category of land (except agricultural land and land of defense) is determined by its owner or user independently within the requirements established by law for the use of land of this category, taking into account urban planning documentation and documentation on land management.

Agricultural land is used by its owners or users solely within the requirements for the use of lands of a certain type of use, established by Articles 31, 33-37 of the Code. Land of defense purposes is used exclusively in accordance with the Law of Ukraine "On the use of land for defense" [2].

Paragraph 6 of article 20 of the Land Code of Ukraine specifies the peculiarities of changing the purpose of specially valuable lands, and paragraph 7 of article 20 specifies the peculiarities of changing the intended purpose of land plots of nature conservation and other nature conservation purposes, historical and cultural, forestry purposes, located in the state or communal property.

Of course, in a market economy, such regulation is foolish, because it is necessary to implement a complex procedure for changing the intended purpose.

Such an approach was introduced with the aim of rational land use and protection. Of course, there is no need to change the intended purpose if it simply sows other grain crops, because such actions will not lead to damage and degradation of the land. Another is the situation in which the land on which the wheat is grown will begin to be used for gardening. For example, lands provided for gardening, in accordance with Article 35, paragraph 3, of the Land Code of 
Ukraine, residential buildings may be built, and construction on land provided for agricultural production is limited.

Some clarity in the solution of this issue is made by the Classification of Types of Land Use Purposes approved by the order of the State Committee of Ukraine for Land Resources No. 538 of July 23, 2010, and registered with the Ministry of Justice of Ukraine on November 1, 2010 under No. 1011/18306 [4]. This document establishes a list of types of intended purposes of land within different categories of land. They should serve the authorities in solving issues related to the purposeful use of land.

Having found out the issues of the conceptual apparatus, we would like to dwell on the procedure for changing the intended purpose.

The legislation provides various procedures for changing the intended purpose of land plots for private ownership and state and communal ownership forms. However, in both cases there are common problems.

Thus, a change in intended purpose of land with state or communal property forms is carried out upon submission of the application (petition) of its user to the relevant executive body or local self-government body, which, in accordance with the powers specified in Article 122 of the Land Code of Ukraine, transfer the ownership or use of such land plots [3].

This is the first (initial) stage, where actors are the users of land (citizens or legal entities) and relevant state authorities or local governments start the procedure of changing the purpose of land. However, what exactly should be indicated in the application (petition), the law is not defined. Citizens or legal entities submit a petition (application) to a village, settlement, city council if the land is located in the communal property form within the boundaries of the settlement or to the district state administration, if the land is state-owned or located outside its borders. In our opinion, the application must indicate the location, area (size), cadastral number of the land plot, the purpose of changing the intended destination, as well as the name of the category of land, the transfer 
to which it is supposed to be implemented. The proposed list is not exhaustive. In particular, it is necessary to add to the application (petition):

1) an infornation from the Land Book on the land plot;

2) documents regarding the restrictions (encumbrances) and land servitudes for use of the land plot;

3) justification of the need to change the intended purpose of the land plot, with its size.

The result of the first stage should be acceptance of the application (petition) and additional documents. It is common knowledge that this procedure is quite painful and can take a long time. In practice, there are numerous cases where the relevant state authorities or local governments refuse to accept the corresponding applications (petitions) of land users on the grounds of their "improper registration in accordance with the established form". To prevent such cases, the content of the application (petition) at this stage should be defined in the legal document.

In the case of changes in the intended purpose of privat land plots, such a change is carried out on the initiative of the owners of land plots without the approval of the Council of Ministers of the Autonomous Republic of Crimea, an executive body, and a local self-government body for its development [3].

At the first (initial) stage, when the individuals act as land owners (citizens or legal entities) and certified land surveyors start the procedure of changing the intended purpose of land plots. However, what exactly should be indicated in the application (petition) is not defined in the legislation. Citizens or legal entities send an application (petition) to the land management organization for the development of a land management project. In our opinion, the application must indicate the location, area (size), cadastral number of the land plot, the aim of changing the intended purpose, as well as the name of the category of land, the transfer to which it is supposed to be implemented. The proposed list is not exhaustive. In particular, it is necessary to add to the application (petition):

1) an information from the Land Book on the land plot; 
2) for the citizen - the owner of the land plot - a copy of the passport (series, passport number, where and by whom issued and place of residence), for the legal entity - the owner of the land plot - a copy of the statute (provision) and a copy of the certificate of state registration of the legal entity;

3) documents concerning the restrictions (encumbrances) and land servitudes for use of the land plot;

4) justification of the need to change the intended purpose of the land plot, with its size.

In our opinion, the basis for changing the intended purpose of land plots should be the justification for the need for such a change. In practice, the basis for justification is urban planning documentation.

However, in accordance with Article 2 of the Law of Ukraine "On Land Management" [1], land management ensures: implementation of state policy on the use and protection of land; implementation of land reform; improvement of land relations; scientific substantiation of the distribution of land by purpose, taking into account state, public and private interests; the formation of a rational system of land tenure and land use, the creation of environmentally sustainable agrolandscapes, etc.

The aforesaid indicates that the scientific justification of the distribution of land according to the intended purpose, taking into account state, public and private interests, should be an integral part of the justification of the necessity to change the intended purpose of the land plot.

At the same time, there is another problem associated with the name of the land management project. In accordance with Article 50 "Land Management Projects for Land Plots" of the Law of Ukraine "On Land Management" [1], land management projects concerning the allocation of land plots are formed in the event of a change in the intended purpose of land plots or the formation of new land plots. However, the land-use process of landing (extraction and rendering) of a land plot differs from the process of changing its intended purpose. 
The main stage of the aforementioned land management process involves the following procedures: drafting, preapproval and approval of the land management project regarding the change of intended purpose of the land plot or part of it; making a decision to change the intended purpose of the land plot. At this stage of land-procedural legal relations concerning the transfer of land new actors are involved, namely: land management organizations, land resources state bodies, environmental and sanitary and epidemiological authorities, the body of urban planning and architecture and the protection of cultural heritage.

It should be noted that the value of land which intended purpose is to be changed depends on the complexity of the procedure for this change. For example, a change in the purpose of specially valuable lands located outside the settlement is carried out after approval by the Verkhovna Rada of Ukraine by the decision of the Cabinet of Ministers of Ukraine. Project materials for approval by the Verkhovna Rada of Ukraine are submitted by the Council of Ministers of the Autonomous Republic of Crimea, the regional state administration.

As a result, it would be desirable to note that in case of disagreement between the owner of the land plot and the decision of the village, settlement, city council or executive body to refuse to change ist intended purpose, the dispute is resolved in court and, as practice shows, is sometimes quite successful.

Conclusions. The land management process of changing the purpose of land plots is regulated by the procedural rules resulting from the multilateral, carried out in the land legal procedure form, the ordered combination of actions of interested persons and authorized bodies of executive power and local self-government, aimed at the official recognition and confirmation by the state facts of change of the intended purpose of a land plot or its part. The current state of the land management process in the area of land use change is not sufficiently regulated in the legislative normative plan, which creates a number of problems for landowners and land users, and requires further research and legislative regulation.

\section{References}


1. The Law of Ukraine "On Land Management" (2003), Kyiv, Vidomosti Verkhovhoi Rady Ukrainy, Available at: http://zakon2.rada.gov.ua/laws/show/858-15/print1476586411943513 （Last viewed 21.07.2018);

2. The Law of Ukraine "On the use of land for defense" (2004), Kyiv, Vidomosti Verkhovhoi Rady Ukrainy, Available at: http://zakon2.rada.gov.ua/laws/show/1345-15 (Last viewed 20.07.2018);

3. Land Code of Ukraine (2002 Kyiv, Vidomosti Verkhovhoi Rady Ukrainy, Available at: http://zakon0.rada.gov.ua/laws/show/276814/print1509545301814503 (Last viewed 19.07.2018);

4. Classification of types of land use purposes (2010), State Committee of Ukraine for Land Resources, Available at: http://zakon2.rada.gov.ua/laws/show/z1011-10/print1443088975422651 (Last viewed 20.07.2018);

5. Kulynych P. (2002), "Land use purposes under the new land code of Ukraine", Yurydychnyi zhurnal, no. 3, pp. 41-46;

6. Tretiak A., Dorosh Y., Kupriyanchyk I. (2017), Theoretical and methodological principles of land management process, Land management, cadastre and land monitoring, no. 4, pp. 3-13;

7. Tretiak A., Dorosh Y., Tretiak R. (2017), „Teoretychni zasady zemlevporiadnoho protsesu: monohrafia", [Theoretical principles of land management process: monograph], in Tretiak A. ed. OLDI-PLIUS, Kherson, Ukraine;

\section{Третяк А.М., Дорош Й.М., Лобунько Ю.В.}

Землевпорядний процес при зміні цільового призначення земельних ділянок: стан та проблеми

Досліджено поняття «основне цільове призначення», «иільове призначення», особливості зміни цілььового призначення різних форм власності земельних ділянок, стадії землевпорядного процесу при зміні 
цільового призначення земельних ділянок. 3'ясовано наявні законодавчонормативні проблеми та шляхи їх вирішення.

Ключові слова. Землевпорядний прочес, зміна цүільового призначення земельних ділянок, проект землеустрою.

\section{Третяк А.М., Дорош И.М., Лобунько Ю.В.}

Землеустроительный процесс при изменении ияелевого назначения земельных участков: состояние и проблемь

Исследовано понятие «основное целевое назначение», «целевое назначение», особенности изменения целевого назначения различных форм собственности земельных участков, стадии землеустроительного процесса при изменении целевого назначения земельных участков. Выяснено имеющиеся законодательно-нормативные проблемы и пути их решения.

Ключевые слова: Землеустроительный процесс, изменение цуелевого назначения земельных участков, проект землеустройства. 